Artikel Penelitian

\title{
Hubungan antara Merokok dan Tingkat Aktivitas Aminotransferase Serum pada Pegawai Kantor
}

\author{
Yelvi Novita Roza ${ }^{1}$, Fadil Oenzil ${ }^{2}$, Dian Pertiwi ${ }^{3}$
}

\begin{abstract}
Abstrak
Aminotransferase serum merupakan salah satu penanda kerusakan hepatoselular. Prevalensi asymptomatic hypertransaminasemia telah mencapai angka 8,9\%. Peningkatan ini diakibatkan perubahan gaya hidup, salah satunya merokok. Tujuan penelitian ini adalah untuk mengetahui hubungan antara kebiasaan merokok termasuk lama merokok, jumlah rokok, derajat perokok dan jenis rokok dengan tingkat aktivitas aminotransferase serum. Desain penelitian ini analitik cross-sectional. Jumlah sampel 68 orang yang diambil secara consecutive sampling. Instrumen dalam penelitian ini ialah kuesioner untuk mendapatkan data responden dan karakteristik kebiasaan merokok, lama merokok, jumlah rokok, dan jenis rokok. Data AST dan ALT pasien didapatkan dari data medical check up Rumah Sakit Semen Padang yang diukur menggunakan metode enzimatik. Data dianalisis dengan uji t-test independent dan uji One Way ANOVA dengan $\mathrm{p}<0,05$ untuk signifikansi. Hasil penelitian mendapatkan adanya hubungan bermakna antara kebiasaan merokok dengan tingkat aktivitas aminotransferase serum $(p=0,001)$ dimana peningkatan AST dipengaruhi oleh lama merokok $(0,003)$, derajat perokok $(0,010)$ dan jenis rokok $(0,020)$. Peningkatan ALT dipengaruhi oleh jumlah rokok $(0,001)$. Simpulan studi ini adalah kebiasaan merokok dapat meningkatkan hipertransaminasemia.
\end{abstract}

Kata kunci: aminotransferase serum, kebiasaan merokok

\begin{abstract}
Serum aminotransferase is one of marker hepatocelluler injury. The prevalence of asymptomatic hypertransaminasemia has reached $8,9 \%$ of the population. It increases because of some changes in lifestyle, one of them is smoking. The objective of this study was to determine the correlation between smoking habits, including duration of smoking, number of cigarettes, degree of smokers, type of cigarettes on serum aminotransferase activity levels. This is cross-sectional analytic study. There were 68 samples which were taken by consecutive sampling. The instrument of this research were questionnaire to get the data of the respondents, smoking habit, duration of smoking, number of cigarette and type of cigarette characteristics, and data of medical check up to get serum aminotransferase levels which determined by enzymatic method. Data were analyzed by $t$-test Independent and One Way ANOVA with $p$ value $<0.05$ for significance. The result of this study showed that there was a correlation between smoking habit and serum aminotransferase level ( $p=0.001)$ which AST levels was influenced by duration of smoking $(p=0.003)$, degree of smoker $(p=0.010)$ and type of smoking $(p=0.020)$ while ALT levels influenced by number of smoking $(p=0.001)$. The conclusion is smoking habit increases the risk of elevated serum aminotransferase levels
\end{abstract}

Keywords: serum aminotransferase, smoking habit

Affiliasi penulis:1. Prodi Profesi Dokter FK Unand (Fakultas Kedokteran Universitas Andalas Padang), 2. Bagian Biokimia FK Unand, 3. Bagian Patologi Klinik FK Unand

Korespondensi :Yelvi Novita Roza,

Email: yelvinovitaroza@yahoo.co.id, Telp: 0853-6474-8699

\section{PENDAHULUAN}

Hepar merupakan salah satu organ kelenjar metabolikterpenting dan terbesar dalam tubuh manusia. Secara fisiologis, organ hepar diketahui terlibat lebih dari 500 pekerjaan yang begitu kompleks, 
salah satunya adalah fungsi detoksifikasi. ${ }^{1}$ Organ hepar bertugas mengeliminasi zat-zat toksik baik berasal dari dalam maupun luar tubuh manusia. Di sisi lain hepar menjadi lebih rentan terhadap kerusakan yang disebabkan oleh zat toksik tersebut. Salah satu metode yang dapat digunakan untuk mengetahui tingkat kerusakan sel hepar adalah pemeriksaan aktivitas Aspartat Aminotransferase (AST) dan Alanin Aminotransferase (ALT) atau dikenal juga sebagai Serum Glutamic Piruvat Transaminase (SGPT) dan Serum Glutamic Oxaloacetat Transaminase (SGOT). ${ }^{2}$

Aspartat aminotransferase adalah enzim yang normalnya terdapat di dalam organel mitokondria otot jantung, ginjal, otot rangka, pankreas dan otak. Alanin aminotransferase cenderung terlokalisasi di dalam sitoplasma sel hepar. Kedua enzim ini sangat penting peranannya dalam proses pembentukan energi. $^{2}$ Apabila sel hepar mengalami kerusakan, maka kedua enzim ini akan keluar dari sel dan beredar bebas di dalam sirkulasi perdaran darah. ALT akan meningkat di dalam darah ketika kerusakan terjadi pada membran sel hepar. Sementara AST akan meningkat di darah apabila kerusakan sudah lebih berat dimana kerusakan telah mencapai subselular organel mitokondria. ${ }^{3}$

Saat ini ditemukan ada kecenderungan abnormalitas tingkat aktivitas aminotransferase pada kelompok populasi yang sehat. Hal ini terungkap dari hasil penelitian yang dilakukan oleh The National Health and Nutrition Examination Survey bahwa terdapat sekitar $8,9 \%$ populasi mengalami asymptomatic hypertransaminasemia. ${ }^{4}$ Ada $80-90 \%$ dari penderita mengalami keadaan perlemakan hepar non alkoholik (Non Alcoholic Fatty Liver Disease/ NAFLD) yang belakangan juga diketahui prevalensinya cenderung meningkat setiap tahunnya. ${ }^{5}$ Selaras dengan hasil studi observasi pendahuluan dari data Medical Check Up (MCU) Rumah Sakit Semen Padang tahun 2013 terdapat $\pm 15,3 \%$ pegawai mengalami hypertransaminasemia. Kerusakan organ hepar bisa disebabkan berbagai faktor, salah satunya pengaruh gaya hidup. Salah satu pengaruh gaya hidup yang berdampak buruk terhadapkesehatan adalah kebiasaan merokok. Berdasarkan data WHO tahun 2008, Indonesia sebagai salah satu negara berkembang menempati posisi ke 3 dunia dengan proporsi perokok terbanyak setelah China dan India. ${ }^{6}$ Berdasarkan laporan dari Kementerian Kesehatan Republik Indonesia tahun 2013, proporsi perokok telah mencapai angka 29,3\% dan jumlah ini mengalami peningkatan dari tahun 2010 sebesar $28,2 \%{ }^{7,8}$ Pada tahun 2007, Sumatera Barat yang juga merupakan salah satu Provinsi di Indonesia pernah menempati posisi 5 teratas dengan jumlah perokok terbanyak diperkirakan lebih dari 1,2 juta orang. ${ }^{9}$

Data tersebut juga senada dengan hasil penelitian yang dilakukan oleh Diana et al di salah satu Perusahaan di Kota Padang tahun 2009 yang menemukan bahwa $84,8 \%$ responden merupakan perokok aktif. Tingginya angka kebiasaan merokok di kalangan pekerja dapat berpengaruh terhadap tingkat produktifitas kerja. ${ }^{10}$

Beberapa tahun terakhir, semakin banyak penelitian yang mengungkapkan adanya kaitan kebiasaan merokok dengan peningkatan risiko gangguan hepar. Meskipun asap rokok tidak berefek langsung terhadap sel hepar namun senyawa toksik yang diabsorbsi dari alveolus ke dalam darah dapat mencapai hepar dan memicu kerusakan yang bersifat irreversibel pada sel hepar. Kandungan nikotin yang terdapat di dalam rokok dapat menyebabkan timbulnya inflamasi pada jaringan hepar. Radikal bebas yang terkandung dalam rokok dapat memicu stress oksidatif pada sel hepar. Merokokdiketahui merupakan salah satu faktor risiko yang dapat memperberat derajat keparahanfibrosis hepar pada pasien denganhepatitisC. ${ }^{11}$ Azzalini et al juga menambahkanbahwa kebiasaan merokokjuga dapat mempercepat proses perkembangan pernyakit perlemakan hepar non alkoholikpada tikusyang diberi asupan diet tinggi lemak. ${ }^{12}$ Studi ini semakin memperkuat teori mengenai adanya hubungan antara merokok dengan kejadian perlemakan hepar. Sayangnya,relevansiklinis dari temuaneksperimental ini masih kontroversial.

Penelitian ini bertujuan untuk mengetahui hubungan antara kebiasaan merokok termasuk lama merokok, jumlah rokok, derajat perokok dan jenis rokok dengan tingkat aktivitas aminotransferase serum. 


\section{METODE}

Jenis penelitian adalah analitik cross-sectional dengan mengambil data rekam medis pegawai kantor yang melakukan kunjungan Medical Check Up ke RS Semen Padang periode 1 Oktober sampai 30 November 2014. Sampel dalam penelitian ini berjumlah 68 orang dan diambil menggunakan teknik consecutive sampling. Kriteria inklusi adalah pegawai kantor laki-laki yang berumur 20-60 tahun yang melakukan kunjungan Medical Check Up ke RS Semen Padang, sedangkan kriteria eksklusi adalah data rekam medis pasien tidak lengkap, mengkonsumsi alcohol/obat-obatan dan menderita penyakit hepatitis, infark miokard, dan diabetes mellitus. Instrumen yang digunakan adalah form pemeriksaan kesehatan dan kuesioner kebiasaan merokok. Prosedur pengumpulan data yaitu diambil dari kuesioner dan rekam medis RS Semen Padang lalu dilakukan evakuasi, pencatatan, pengolahan dan analisis data. Analisis data terdiri dari analisis univariat dan bivariat.

HASIL

Berdasarkan data yang diperoleh dari pengisian kuesioner dan hasil pemeriksaan kesehatan pegawai kantor yang melakukan kunjungan Medical Check Up periode Oktober sampai November 2014 ke Rumah Sakit Semen Padang, didapatkan hasil penelitian sebagai berikut:

\section{Karakteristik Responden}

Tabel 1. Karakteristik responden secara umum

\begin{tabular}{lccc}
\hline Karakteristik & Kategori & $\mathbf{n}$ & $\mathbf{\%}$ \\
& & $\mathbf{( 6 8 )}$ & $\mathbf{( 1 0 0 )}$ \\
\hline Umur & 21-30 tahun & 23 & 33,8 \\
$31-40$ tahun & 16 & 23.5 \\
41-50 tahun & 15 & 22,1 \\
51-60 tahun & 14 & 20,6 \\
\hline Aktivitas AST Normal & & 52 & 76,5 \\
Abnormal & 16 & 23,5 \\
\hline Aktivitas ALT Normal & & 50 & 73,5 \\
Abnormal & 18 & 26,5 \\
\hline Kebiasaan Merokok & & 37 & 54,4 \\
Merokok & Tidak Merokok & 31 & 45,6
\end{tabular}

Berdasarkan Tabel 1 dapat diketahui bahwa responden terbanyak berada pada usia 21-30 tahun yaitu sebanyak 23 orang $(33,8 \%)$. Dari total 68 responden terdapat $16(23,5 \%)$ memiliki tingkat AST abnormal dan 18 responden $(26,5 \%)$ memiliki tingkat ALT abnormal. Hasil penelitian ini terlihat bahwa proporsi pegawai kantor yang mengalami hipertransaminasemia saat ini meningkat dibanding proporsi hipertransaminasemia pegawai yang melakukan kunjungan Medical Check Up pada tahun 2013 di Rumah Sakit Semen Padang yang hanya sebesar $15,3 \%$. Jumlah responden merokok dalam penelitian ini ialah 37 orang $(54,4 \%)$ dan tidak merokok sebanyak 31 orang (45,6\%). Artinya lebih dari setengah responden merupakan perokok.

\section{Karakteristik Merokok Responden}

Tabel 2. Karakteristik merokok responden

\begin{tabular}{cccccc}
\hline & $\mathbf{f}$ & Rerata & SD & Min & Maks \\
\hline $\begin{array}{c}\text { Lama Merokok } \\
\text { (tahun) }\end{array}$ & 37 & 18,3 & 9,5 & 3 & 35 \\
\hline $\begin{array}{c}\text { Jumlah Rokok } \\
\text { (batang) }\end{array}$ & 37 & 18,35 & 6,977 & 3 & 35 \\
\hline $\begin{array}{c}\text { Derajat Perokok } \\
\text { (indeks) }\end{array}$ & 37 & 351,8 & 227,7 & 15 & 1015 \\
\hline
\end{tabular}

Tabel 2 menggambarkan lama rata-rata merokok responden ialah $18,3 \pm 9,5$ tahun dengan waktu maksimal lama merokok selama 35 tahun dan minimal 3 tahun. Jumlah rata-rata batang rokok yang dihisap setiap harinya adalah 18,35 $\pm 6,977$ batang dengan jumlah maksimal rokok yang dihisap perhari sebanyak 35 batang dan minimal 3 batang. Nilai ratarata hasil kali lama merokok dengan jumlah rokok yang dihisap sehari (derajat perokok) berjumlah $351,8 \pm 227,7$ atau dapat dikategorikan derajat perokok sedang. Nilai minimum dari derajat perokok responden ialah 15 dan nilai maksimumnya ialah 1015.

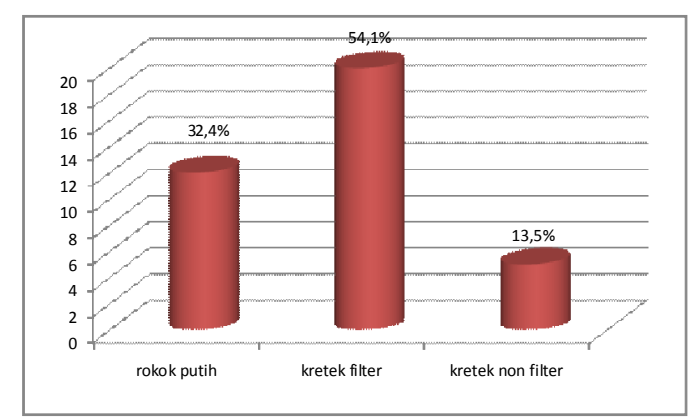

Gambar 1. Distribusi frekuensi jenis rokok responden 
Berdasarkan Gambar 1 didapatkan jenis rokok yang dihisap responden terbanyak ialah jenis kretek filter dengan jumlah 20 responden $(54,1 \%)$.

\section{Hubungan Kebiasaan Merokok dengan Aktivitas} Aminotransferase Serum

Berdasarkan uji t-independen, hubungan kebiasaan merokok dengan tingkat aktivitas aminotransferase serum pada pegawai kantor dapat dilihat pada Tabel 3.

Tabel 3. Hubungan kebiasaan merokok dengan tingkat aktivitas aminotransferase serum

\begin{tabular}{|c|c|c|c|}
\hline \multirow[b]{2}{*}{ Parameter } & \multicolumn{2}{|c|}{ Rerata $\pm S D$} & \multirow[b]{2}{*}{$\mathbf{p}$} \\
\hline & $\begin{array}{c}\text { Perokok } \\
(n=37)\end{array}$ & $\begin{array}{c}\text { Bukan } \\
\text { Perokok } \\
(n=31)\end{array}$ & \\
\hline AST & $35,52 \pm 1,38$ & $25,57 \pm 1,50$ & 0,001 \\
\hline ALT & $36,28 \pm 1,62$ & $23,97 \pm 1,69$ & 0,001 \\
\hline
\end{tabular}

Hubungan Lama Merokok dengan Tingkat Aktivitas Aminotransferase Serum

Lama merokok responden dibagi menjadi 3 kategori, yaitu $<10$ tahun, 10-20 tahun, dan $>20$ tahun. Berdasarkan uji One Way ANOVA, hubungan lama merokok dengan tingkat aktivitas aminotransferase serum pada pegawai kantor dapat dilihat dibawah ini.

Hubungan Jumlah Batang Rokok dengan Tingkat Aktivitas Aminotransferase Serum

Hasl uji statistik yang dilakukan, hubungan jumlah batang rokok yang dihisap perhari dengan tingkat aktivitas aminotransferase serum pada pegawai kantor dapat dilihat pada Tabel 4.

Tabel 4. Hubungan lama merokok dan jumlah rokok dengan tingkat aktivitas aminotransferase serum

\begin{tabular}{|c|c|c|c|}
\hline & \multirow{2}{*}{$\begin{array}{c}\mathbf{n} \\
(37)\end{array}$} & \multicolumn{2}{|c|}{ Mean $\pm S D$} \\
\hline & & AST & ALT \\
\hline \multicolumn{4}{|l|}{ Lama Merokok } \\
\hline$<10$ tahun & 8 & $25,70 \pm 1,30$ & $36,27 \pm 1,72$ \\
\hline 10-20 tahun & 13 & $25,57 \pm 4,68$ & $23,97 \pm 1,50$ \\
\hline$>20$ tahun & 16 & $41,67 \pm 1,40$ & $33,88 \pm 1,64$ \\
\hline Nilai $p$ & & 0,003 & 0,251 \\
\hline \multicolumn{4}{|l|}{ Jumlah Rokok } \\
\hline$<10$ batang & 3 & $26,91 \pm 1,34$ & $21,87 \pm 1,32$ \\
\hline 10-20 batang & 23 & $33,88 \pm 1,32$ & $33,11 \pm 1,62$ \\
\hline$>20$ batang & 11 & $41,68 \pm 1,35$ & $51,28 \pm 1,35$ \\
\hline Nilai $p$ & & 0,088 & 0,001 \\
\hline
\end{tabular}

Hubungan Derajat Perokok dengan Tingkat

AktivitasAminotransferase Serum

Berdasarkan uji statistik One Way Anova, hubungan derajat perokok dengan tingkat aktivitas aminotransferase serum pada pegawai kantor dapat dilihat pada Tabel 5.

Hubungan Jenis Rokok dengan Tingkat Aktivitas Aminotransferase Serum

Berdasarkan uji statistik, hubungan jenis rokok yang dihisap dengan tingkat aktivitas aminotransferase serum pada pegawai kantor dapat dilihat pada Tabel 5

Tabel 5. Hubungan derajat perokok dan jenis rokok dengan tingkat aktivitas aminotransferase serum

\begin{tabular}{|c|c|c|c|}
\hline & \multirow{2}{*}{$\begin{array}{c}\mathbf{n} \\
(37)\end{array}$} & \multicolumn{2}{|c|}{ Rerata Geometrik } \\
\hline & & AST & ALT \\
\hline \multicolumn{4}{|l|}{ Derajat Perokok } \\
\hline Ringan & 10 & 28,24 & 30,76 \\
\hline Sedang & 22 & 34.48 & 30,96 \\
\hline Berat & 5 & 49,26 & 45,45 \\
\hline Nilai $p$ & & 0,010 & 0,435 \\
\hline \multicolumn{4}{|l|}{ Jenis Rokok } \\
\hline Rokok Putih & 12 & 27,25 & 33,11 \\
\hline Kretek Filter & 20 & 37,45 & 38,02 \\
\hline Kretek non Filter & 5 & 38,02 & 35,48 \\
\hline Nilai $p$ & & 0,020 & 0,735 \\
\hline
\end{tabular}

\section{PEMBAHASAN}

Hubungan Kebiasaan Merokok dengan Aktivitas Aminotransferase Serum

Berdasarkan Tabel 3 diketahui bahwa rerata aktivitas AST dan ALT serum lebih tinggi pada perokok secara signifikan dibandingkan responden bukan perokok. Menurut penelitian Khaled dan Rahab menyatakan bahwa terdapat perbedaan bermakna aktivitas aminotransferase serum antara perokok dan bukan perokok. ${ }^{13}$

Hal ini sejalan dengan kepustakaan, bahwa senyawa kimia yang terkandung di dalam rokok merupakan senyawa kimia berbahaya dan toksik bagi tubuh. Beberapa diantaranya ialah nikotin, karbon monoksida, nitrit oksida, dan berbagai macam radikal bebas. Asap rokok mengandung radikal bebas dalam jumlah yang sangat tinggi diperkirakan dalam satu kali 
hisapan terdapat $10^{14}$ molekul radikal bebas. Radikal bebas merupakan atom sangat reaktif yang dapat memicu stress oksidatif terhadap sel hepar. Apabila terjadi kerusakan terhadap membran sel hepar akibat peroksidasi lipid oleh radikal bebas maka dapat menyebabkan keluarnya ALT dan masuk ke dalam darah. Namun, apabila kerusakan sudah mencapai organel mitokondria maka dapat menyebabkan AST keluar dari sel dan masuk ke dalam aliran darah. Hal ini yang menyebabkan peningkatan aktivitas aminotransferase serum pada perokok. ${ }^{14}$

\section{Hubungan Lama Merokok dengan Aktivitas Aminotransferase Serum}

Hasil uji statistik menggunakan uji One Way ANOVA, dapat dilihat hasil pada Tabel 4 bahwa terdapat perbedaan rerata bermakna aktivitas AST pada kelompok perokok lebih dari 20 tahun dibandingkan dengan kelompok lama merokok antara 10-20 tahun dan kurang dari 10 tahun. Rerata aktivitas ALT tidak berbeda secara bermakna diantara ketiga kelompok tersebut. Hal ini sesuai dengan penelitian Elkarim et al yang menyatakan bahwa terdapat korelasi positif antara lama merokok dengan tingkat aktivitas AST $(p=0,001)$, sedangkan hubungan lama merokok dengan ALT yang juga merupakan salah satu parameter yang digunakan dalam penelitian tersebut tidak menunjukkan korelasi yang bermakna terhadap lama merokok seseorang $(p>0,05){ }^{15}$

Hal ini sesuai dengan kepustakaan bahwa paparan asap rokok yang bersifat menahun dapat menimbulkan kerusakan sel yang bersifat kronik. Kondisi ini salah satunya ditandai dengan adanya infiltrasi sel dan mediator inflamasi kronik secara persisten akibat paparan senyawa kimia rokok yang berlangsung terus-menerus, diantaranya sel kuppfer dan berbagai sitokin yang disekresikan. ${ }^{16}$ Pada penelitian ini didapatkan bahwa rerata lama merokok responden mencapai 18 tahun. Hal ini menandakan bahwa paparan asap rokok terhadap responden dalam penelitian sudah berlangsung menahun sehingga proses kerusakan sel yang terjadi tidak lagi bersifat akut namun bersifat kronis. Pada kondisi ini, AST yang terdapat baik dalam sitoplasma maupun yang terdapat didalam organel mitokondria akan meningkat lebih tinggi dibandingkan ALT di dalam darah. ${ }^{3}$ Hal ini juga sesuai dengan penelitian Nalpas et al bahwa aspartat aminotransferase mitokondria menjadi salah satu penanda kerusakan sel hati kronis. ${ }^{17}$ Penelitian eksperimental pada tikus yang dipapar asap rokok secara kronis menyebabkan eksaserbasi perlemakan hepar pada tikus obes daripada tikus kontrol yang juga memperlihatkan adanya peningkatan signifikan aktivitas aminotransferase pada tikus tersebut. Hal ini menunjukkan besarnya pengaruh lama merokok seseorang terhadap tingkat kerusakan hepar. Semakin lama sesorang memiliki kebiasaan merokok, maka semakin tinggi risiko menderita kerusakan hepar. ${ }^{12}$

\section{Hubungan Jumlah Rokok dengan Aktivitas} Aminotransferase Serum

Uji statistik One Way ANOVA didapatkan hasil seperti yang tercantum dalam Tabel 4 bahwa terdapat perbedaan rerata aktivitas ALT secara signifikan pada responden yang merokok lebih dari 20 batang sehari dengan responden yang merokok 10-20 batang dan kurang dari 10 batang sehari. Aktivitas AST tidak memperlihatkan perbedaan yang bermakna diantara tiga kelompok. Hal ini sesuai dengan penelitian Jang et al yang menyatakan terdapat hubungan signifikan antara jumlah rokok yang dihisap perhari dengan peningkatan aktivitas aminotransferase. ${ }^{18}$

Hal ini sesuai dengan kepustakaan bahwa respon sel terhadap stimulus berbahaya dapat dipengaruhi salah satunya oleh besaran dosis paparan yang diterima. Penelitian epidemiologi menunjukkan bahwa senyawa toksik rokok dapat meningkatkan aktivitas ALT. $^{19}$ Peningkatan ALT serum terhadap tingkat jumlah batang rokok yang dihisap ternyata juga dapat dipengaruhi oleh polimorfisme genetik ND2-237 Leu dan ND2-237 Met yang merupakan bagian mitokondrial DNA. NADH dehidrogenase merupakan salah satu enzim yang dapat menghasilkan produk ROS di dalam mitokondria dan sekaligus merupakan salah satu target kerusakan oleh reactive oxygen species ROS. Genotip ND2-237 Met berfungsi menekan produksi ROS dan mencegah kerusakan lanjut pada mitokondria. Hal ini yang menyebabkan polimorfisme genotip ND2-237 Met akan dapat menyebabkan peningkatan ALT saja, karena adanya 
efek protektif genotip tersebut terhadap organel mitokondria. ${ }^{20}$

\section{Hubungan Derajat Perokok dengan Aktivitas Aminotransferase Serum}

Derajat perokok menurut Brinkmann adalah hasil kali dari jumlah rokok yang dihisap sehari dengan lama seseorang merokok. Dalam penelitian ini derajat perokok responden dibagi menjadi tiga, yaitu kategori ringan dengan indeks Brinkmann 0-200, kategori sedang dengan indeks Brinkmann 200-600, dan kategori berat dengan indeks Brinkmann lebih dari 600. Frekuensi derajat perokok responden tertinggi berada pada kategori perokok sedang dengan jumlah responden sebanyak 22 dari 37 responden perokok $(59,5 \%)^{21}$

Berdasarkan hasil analisis uji statistik yang dilakukan, didapatkan hasil seperti yang terlihat pada tabel bahwa aktivitas AST ditemukan berbeda secara signifikan $(p<0,05)$ antara perokok berat dengan perokok sedang atau ringan. Hal ini sesuai dengan hasil penelitian Park et al yang menyatakan bahwa perokok berat memiliki risiko lebih tinggi mengalami peningkatan $\mathrm{AST}^{22}$

Derajat kerusakan sel dapat berbeda-beda tergantung durasi, dosis, tipe dan keparahannya. Toksin yang berdosis rendah dengan paparan berdurasi singkat hanya menimbulkan jejas yang bersifat reversibel, sedangkan toksin berdosis lebih tinggi dan dalam waktu yang lebih lama akan menyebabkan jejas irreversibel dan kematian sel. ${ }^{16}$ Aktivitas AST yang meningkat pada perokok berat menandakan telah terjadi kerusakan yang lebih berat. Hal ini terjadi karena adanya efek sinergistik yang ditimbulkan dari senyawa toksik rokok yang terakumulasi lama di dalam tubuh. Asap rokok dapat memicu kerusakan pada hepar melalui tiga mekanisme yaitu secara langsung melalui substansi kimia yang bersifat sitotoksik, kemudian secara tidak langsung melalui akumulasi zat besi yang diakibatkan proses turn over eritrosit berlebihan karena kondisi polisitemia sekunder dan juga melalui potensi substansi onkogenik yang terkandung dalam rokok. Semua kondisi ini dapat menyebabkan kerusakan hepar pada perokok berat. ${ }^{23}$
Hubungan Jenis Rokok dengan Aktivitas

Aminotransferase Serum

Kategori jenis rokok dalam penelitian ini dibagi menjadi 3 yaitu rokok putih (nikotin $<1 \mathrm{mg}$ dan tar $<$ $13 \mathrm{mg}$ ), kretek filter (nikotin $<1,5 \mathrm{mg}$ dan tar $<20 \mathrm{mg}$ ), dan kretek non filter (nikotin $>1,5 \mathrm{mg}$ dan tar $>20$ $\mathrm{mg}$ ). Hasil wawancara didapatkan frekuensi jenis rokok yang dihisap responden tertinggi adalah perokok yang menghisap jenis rokok filter yaitu sebanyak 20 responden $(54,1 \%)$.

Hasil analisis bivariat dengan uji One Way ANOVA diperoleh hasil adanya perbedaan rerata AST diantara ketiga kelompok tersebut, dimana rerata aktivitas AST tertinggi terdapat pada perokok yang mengkonsumsi jenis rokok kretek non filter $(p<0,05)$ sedangkan nilai rerata ALT tidak menunjukkan perbedaan yang signifikan diantara ketiga kelompok.

Hal ini sejalan dengan penemuan oleh Alderson et al bahwa senyawa karsinogen dan radikal bebas yang terkandung dalam asap utama rokok dapat dikurangi saat masuk ke dalam tubuh menggunakan filter. ${ }^{24}$ Berbagai penelitian epidemiologi menemukan rendahnya risiko kanker pada perokok yang menggunakan rokok filter dibandingkan perokok yang mengkonsumsi rokok tanpa filter. Keganasan merupakan salah satu bentuk kerusakan hepar yang bersifat kronis yang dapat terjadi karena adanya induksi dari senyawa karsinogen yang terkandung dalam rokok diantaranya nitrosamine, benzo(a)pyrene, polycyclic aromatic hydrocarbon (PAH). Senyawa karsinogen menyerang langsung struktur DNA baik yang berada di dalam nukleus ataupun di dalam mitokondria sel hepar dan menimbulkan kerusakan yang bersifat irreversibel pada sel hepar. Salah satu penanda kerusakan kronis dari sel hepar adalahpeninggian aktivitas AST serum. ${ }^{3}$ Penggunaan rokok jenis kretek non filter jauh lebih berbahaya karena dapat menyerang struktur inti sel dan mengakibatkan gangguan pusat koordinasi dalam sel yang berujung pada keganasan dan kematian sel.

\section{Keterbatasan Penelitian}

Desain penelitian ini adalah studi potong lintang (cross sectional) dimana variabel independen dan dependen diobservasi satu kali pada saat yang sama. 
Hal tersebut menjadikan penelitian ini tidak dapat menggambarkan perkembangan penyakit secara akurat. Penelitian ini hanya memperhitungkan efek merokok aktif terhadap tingkat aktivitas aminotransferase, tanpa memperhitungkan efek dari paparan rokok secara pasif. metode pengisian kuesioner yang digunakan untuk menentukan kebiasaan merokok dalam penelitian ini membuat responden mengandalkan daya ingatnya dalam menjawab pertanyaan-pertanyaan kuesioner.

\section{SIMPULAN}

Terdapat hubungan bermakna antara kebiasaan merokok dengan tingkat aktivitas aminotransferase serum dimana peningkatan AST dipengaruhi oleh lama merokok, derajat perokok dan jenis rokok. Sementara peningkatan ALT hanya dipengaruhi oleh jumlah rokok.

\section{DAFTAR PUSTAKA}

1. Amirudin R. Fisiologi dan biokimia hati. Dalam: Buku Ajar IImu Penyakit Dalam. Edisi ke-4. Jakarta: Internal Publishing. 2009.hlm.627-33.

2. Murray RK. Katabolisme protein dan nitrogen asam amino. Dalam: Harper's Illustrated Biochemistry. Edisi ke-27. Boston: McGraw-Hill. 2006. hlm.27993.

3. Speicher CE, Smith JW. Pemilihan uji laboratorium yang efektif. Jakarta: EGC; 1996. hlm.232-54.

4. Ioannou GN, Boyko EJ, Lee SP. The prevalence and predictors of elevated serum aminotransferase activity in the United States in 1999-2002. 2006. (diunduh 18 Desember 2013). Tersedia dari: URL: HYPERLINK http://www.ncbi.nlm.nih.gov/pubmed/ 164055371

5. Oh SY, Cho YK, Kang MS, Yoo TW, Park JH, Kim $\mathrm{HJ}$, et al. The association between increased alanine aminotransferase activity and metabolic factors in nonalcholic fatty liver disease. 2006. (diunduh 20 Oktober 2013). Tersedia dari: URL: HYPERLINK http://www.ncbi.nlm.nih.gov/pubmed/ $\underline{17142131 /}$

6. World Health Organization (WHO). WHO Report on The Global Tobacco Epidemic 2008. Implementing Smoke-Free Environment. 2008 (diunduh 1 November 2013). Tersedia dari: URL: HYPERLINK http://www.ncbi.nlm.nih.gov/pubmed/ 17142131/(www.who.int/tobacco/mpower)

7. Litbang Departemen Kesehatan RI. Riset kesehatan Dasar 2013 (diunduh 3 April 2014). Tersedia dari: URL: HYPERLINK http://www. litbang.depkes.go.id/sites/download/rkd2013/Lapor an Riskesdas2013.PDF

8. Litbang Departemen Kesehatan RI. Riskesdas 2010 (diunduh 3 April 2014). Tersedia dari: URL: HYPERLINK http://www.litbang.depkes.go.id/ sites/download/buku laporan/lapnas riskesdas201 0/Laporan riskesdas 2010.pdf

9. Litbang Departemen Kesehatan RI. Riskesdas 2007 (diunduh 3 April 2014). Tersedia dari: URL: HYPERLINKhttps://www.k4health.org/sites/default/ files/laporanNasional\%20Riskesdas\%202007.pdf

10. Diana D, Bustaman B, Juli K. Low physical activity work-related and other risk factors increased the risk of poor physical fitness in cement workers. 2009 (diunduh 1 November 2013). Tersedia dari: URL: HYPERLINK http://mji.ui.ac.id/journal/index. php/mii/article/view/362

11. Pessione F, Ramond MJ, Njapoum C, Duchatelle V, Degott C, Erlinger S, et al. Cigarette smoking and hepatic lesions in patients with chronic hepatitis C. 2001 (diunduh 22 Januari 2014). Tersedia dari: URL: HYPERLINK http://www.ncbi. nlm.nih.gov/pubmed/11431742

12. Azzalini L, Ferrer E, Ramalho LN, Moreno M, Domínguez $\mathrm{M}$, Colmenero $\mathrm{J}$, et al. Cigarette smoking exacerbates nonalcoholic fatty liver disease in obese rats. 2010 (diunduh 22 Januari 2014). Tersedia dari: URL: HYPERLINK http://www.ncbi.nlm.nih.gov/pubmed/20432253

13. Khaled AS, Rahab D. Effect of cigarette smoking on liver functions: a comparative study conducted among smokers and non-smokers male in El-beida City, Libya. 2014 (diunduh 2 Januari 2015). Tersedia dari: URL: HYPERLINK http://www. icpionline.com/documents/Vol3/ssue7/01.pdf

14. Ramamurthy, Raveendran,Shirumeni, Krishnaveni. Biochemical changes of cigarette smokers and non-cigarette smokers. 2012 (diunduh 2 Januari 2015). Tersedia dari: URL: HYPERLINK 
http://www.academia.edu/2230270/Biochemical ch anges of cigarette smokers and noncigarette smokers

15. Elkarim A, Alhibiril M, Lutfi M. Influence of chronic cigarette smoking on serum biochemical Profile among Sudanese smokers. 2013. (diunduh 18 Desember 2014). Tersedia dari: URL: HYPERLINK http://www.jbiopharm.com/index.php/ ajbps/article/view/224

16. Kumar V, Abbas AK, Fausto N. Pathologic basis of disease. 7 Edisi ke-7. Philadelphia: Elsevier; 2007.hIm. 43-60

17. Nalpas B, Vassault A, Charpin S, Lacour B, Berthelot $P$. Serum mitochondrial aspartate aminotransferase as a marker of chronic alcoholism: diagnostic value and interpretationin a liver unit. 1986 (diunduh 18 Desember 2014). Tersedia dari: URL: HYPERLINK http://www.ncbi. nlm.nih.gov/pubmed/3732996

18. Jang E , Jeong S, Hwang S, Kim H, Ahn S, Lee $\mathrm{J}$, et al. Effects of coffee, smoking, and alcohol on liver function tests: a comprehensive crosssectional study. 2012 (diunduh 18 November 2014). Tersedia dari: URL: HYPERLINK http://www.ncbi.nlm.nih.gov/pubmed/23075166

19. Wang CS, Wang ST, Chang TT, Yao WJ, Chou P. Smoking and alanine aminotransferase levels in hepatitis C virus infection. 2002 (diunduh 18 Agustus 2014). Tersedia dari: URL: HYPERLINK http://www.ncbi.nlm.nih.gov/pubmed/11926856

20. Kokaze A, Yoshida M, Ishikawa M, Matsunaga N, Karita $\mathrm{K}$, Ohtsu $\mathrm{T}$, et al. NADH dehydrogenase subunit-2 237 Leu/Met polymorphism modifies effects of cigarette smoking on risk of elevated levels of serum liver enzyme in male Japanese health check-up examinees: a cross-sectional study. 2014. (diunduh 18 Desember 2014). Tersedia dari: URL: HYPERLINK http://www.ncbi. nlm.nih.gov/pubmed/25031572

21. Brinkman GL, Coates EO Jr. The effect of bronchitis, smoking, and occupation on ventilation. 1963 (diunduh 2 Oktober 2014). Tersedia dari: URL: HYPERLINK http://www.ncbi.nlm.nih.gov/ pubmed/14015517

22. Park EY, Lim MK, Oh JK, Cho H, Bae MJ, Yun EH, et al. Independent and supra additive effect of alcohol consumption, cigarette smoking, and metabolic syndrome on the elevation of serum liver enzyme levels. 2013 (diunduh 18 Agustus 2014). Tersedia dari: URL: HYPERLINK http://journals. plos.org/plosone/article?id=10.1371/journal . pone. 0 $\underline{063439}$

23. El-Zayadi AR, Selim O, Hamdy H, El-Tawil A, Moustafa $H$. Heavy cigarette smoking induce hypoxic policytemia and hyperuricemia in chronic hepatitis C patient with reversal of clinical symptoms and laboratory parameter with therapeutic phlebotomy. 2002 (diunduh 23 Januari 2014). Tersedia dari: URL: HYPERLINK http://www.ncbi.nlm.nih.gov/pubmed/12014742

24. Alderson MR, Lee PN, Wang R. Risks of lung cancer, chronic bronchitis, ischaemic heartdisease, and stroke in relation to type of cigarette smoked. 1985 (diunduh 6 Agustus 2014). Tersedia dari: URL: HYPERLINK http://jech.bmj.com/content/ 39/4/286.full.pdf+html 